\title{
Educ ação, identidade negra e formação de profess ores/as: um olhar sobre o corpo negro e o cabelo crespo
}

Nilma Lino Gomes

Universidade Federal de Minas Gerais

Correspondência: Nilma Lino Gomes

Rua Itaparica, 216 apto. 102 - Serra

30240-130 - Belo Horizonte - MG

E-mail: nilmagomes@uol.com.br

\section{Resumo}

Este artigo discute as particularidades e possíveis relações entre educação, cultura, identidade negra e formação de professores/as, tendo como enfoques principais a corporeidade e a estética. Para tal, apresenta a necessidade de articulação entre os processos educativos escolares e não-escolares e a inserção de novas temáticas e discussões no campo da formação de professores/as.

Dando continuidade às reflexões realizadas pela autora na sua tese de doutorado, discutem-se as representações e as concepções sobre o corpo negro e o cabelo crespo, construídas dentro e fora do ambiente escolar, a partir de lembranças e depoimentos de homens e mulheres negras entrevistados durante a realização de uma pesquisa etnográfica em salões étnicos de Belo Horizonte. Para essas pessoas, a experiência com o corpo negro e o cabelo crespo não se reduz ao espaço da família, das amizades, da militância ou dos relacionamentos amorosos. A escola aparece em vários depoimentos como um importante espaço no qual também se desenvolve o tenso processo de construção da identidade negra.

Lamentavelmente, nem sempre ela é lembrada como uma instituição em que o negro e seu padrão estético são vistos de maneira positiva. 0 entendimento desse contexto revela que o corpo, como suporte de construção da identidade negra, ainda não tem sido uma temática privilegiada pelo campo educacional, principalmente pelos estudos sobre formação de professores e diversidade étnico-cultural. E que esse campo, também, ao considerar tal diversidade, deverá se abrir para dialogar com outros espaços em que os negros constroem suas identidades. Muitas vezes, locais considerados pouco convencionais pelo campo da educação, como por exemplo, os salões étnicos.

\section{Palavras-chave}

Cultura - Formação de professores/as - Identidade negra - Estética. 


\title{
Educ ation, black identity, and te a cher educ ation: a look upon the black body and hair
}

Nilma Lino Gomes

Universidade Federal de Minas Gerais

\begin{abstract}
This article discusses the specificities and possible relations between education, culture, black identity, and teacher education, approaching them from the perspective of corporeity and aesthetics. For that, the text introduces the need to articulate education and non-education processes, to insert new themes and discussions into the field of teacher education.

Following on the considerations made by the author in her doctoral thesis, the representations and notions about the black body and hair constructed inside and outside school are discussed, based on memories and testimonies of black men and women interviewed during an ethnographic study carried out in ethnic beauty shops in Belo Horizonte. For those people, the experience with the black body and hair is not restricted to the family environment, friendships, militancy or love life. The school appears in several testimonies as an important space in which the tense process of construction of the black identity also takes place.

Sadly, the school is not often remembered as an institution where black people and their aesthetic standards are viewed positively. The appreciation of this context reveals that the body, as a support for the construction of the black identity, still has to be taken up as a theme of choice by the educational field, particularly in the studies on teacher education and ethnic-cultural diversity. It also shows that, when considering such diversity, this field of study will have to open itself to the dialogue with other spaces where black people also construct their identity, spaces such as beauty shops, many times regarded as unconventional in the field of education.
\end{abstract}

Contact:

Nilma Lino Gomes

Rua Itaparica, 216 apto. 102 - Serra

30240-130 - Belo Horizonte - MG

E-mail; nilmagomes@uol.com.br
Keywords:

Culture - Teacher education - Black identity - Aesthetics. 
A formação de professores/ras tem sido uma preocupação constante do campo da educação. O MEC, a universidade, os centros de formação de professores, as escolas, enfim, todos se preocupam e concordam que é preciso hoje formá- los mais adequadamente tanto em seu percurso inicial quanto em serviço. Mas apenas investir numa melhor formação não é 0 suficiente. A formação de professores/ras, sobretudo a que visa a diversidade, deveria considerar outras questões, tais como: como os/as professores/ras se formam no cotidiano escolar? Atualmente, quais são as principais necessidades formadoras dos/das docentes? Que outros espaços formadores interferem na sua competência profissional e pedagógica? Que temas os/as professores/ras gostariam de discutir e de debater no seu percurso de formação e no dia-a-dia da sala de aula? E que temáticas sociais e culturais são omitidas, não são discutidas ou simplesmente não são consideradas importantes para a sua formação profissional e para o processo educacional dos seus alunos? Será que a questão racial está incluída nessas temáticas omitidas ou silenciadas? ${ }^{1}$

Sabemos que existem vários artigos, livros e pesquisas que discutem a relação entre a questão racial e a educação. Porém, seria interessante pesquisar se a produção teórica sobre raça e educação, e negro e educação, tem destacado a articulação entre identidade negra, cultura negra e formação de professores.

Seria simplificar o problema dizer que tudo o que produzimos sobre a questão racial na educação e em outras áreas do conhecimento pode ser aproveitado e aplicado na formação de professores. Estamos diante do desafio de analisar a produção acadêmica existente sobre relações raciais no Brasil e discutir quais aspectos dessa produção devem fazer parte dos processos de formação dos docentes. Resta ainda outro desafio, o de descobrir como a produção sobre o negro e sua cultura, realizada por outras áreas do conhecimento, poderá nos ajudar a refletir sobre a temática negro e educação, enriquecendo e apontando novos caminhos para o campo da formação de professores.
Será que conhecemos os estudos e as pesquisas realizados pela antropologia, pela sociologia, pela psicologia social, pela história, pela comunicação social, entre outros, que têm as relações raciais como objeto de investigação? Ao conhecermos tais estudos, refletimos sobre as possíveis relações entres estes e 0 campo da educação, e vice-versa? A articulação entre a produção teórica educacional sobre o negro e a produção que tem sido realizada por diferentes áreas do conhecimento sobre a mesma temática poderá nos ajudar a descobrir novas dimensões da realidade racial brasileira? 0 conhecimento dessas dimensões não poderá ser incorporado como mais uma competência dos educadores nos seus processos de formação? Sem dúvida, os questionamentos acima nos mostram que essa não é uma tarefa fácil. Para realizá-la será preciso entender e considerar a importância da articulação entre cultura, identidade negra e educação. Uma articulação que se dá nos processos educativos escolares e não-escolares.

\section{O olhar sobre a identidade negra: uma forma de articular cultura, educação e formação de professores}

Um dos primeiros caminhos a serem triIhados nessa direção poderá ser o da inserção, nos cursos de formação de professores e nos processos de formação em serviço, de disciplinas, debates e discussões que privilegiem a relação entre cultura e educação, numa perspectiva antropológica.

A perspectiva antropológica nos ajuda a compreender que a cultura, seja na educação ou nas ciências sociais, é mais do que um conceito acadêmico. De acordo com Denys Cuche (1999), ela diz respeito às vivências concretas dos sujeitos, à variabilidade de formas de conceber 0 mundo, e às particularidades e semelhanças construídas pelos seres humanos ao longo do processo histórico e social.

1. A partir deste momento, o texto abandona a fórmula "o(a)" ou o par negros e negras, 0 docente e a docente, adotando o genérico masculino. 
Os homens e as mulheres, por meio da cultura, estipulam regras, convencionam valores e significações que possibilitam a comunicação dos indivíduos e dos grupos. Por meio da cultura eles podem se adaptar ao meio, mas também o adaptam a si mesmos e, mais do que isso, podem transformá-lo.

Laraia (2001, p. 67) nos relata que Ruth Benedict escreveu, em 0 crisântemo e a espa$d a$, que a cultura é como uma lente através da qual o homem vê o mundo. Sendo assim, homens e mulheres de diferentes culturas usam lentes diversas e, portanto, não têm a mesma visão das coisas. Ainda segundo esse autor:

o modo de ver o mundo, as apreciações de ordem moral e valorativa, os diferentes comportamentos sociais e mesmo as posturas corporais são assim produtos de uma herança cultural, ou seja, o resultado da operação de uma determinada cultura. (Laraia, 2001, p.68)

Entre os processos culturais construídos pelos homens e pelas mulheres na sua relação com o meio, com os semelhantes e com os diferentes, estão as múltiplas formas por meio das quais esses sujeitos se educam e transmitem essa educação para as futuras gerações. É por meio da educação que a cultura introjeta os sistemas de representações e as lógicas construídas na vida cotidiana, acumulados (e também transformados) por gerações e gerações.

Por isso, ao discutirmos a relação entre cultura e educação, é sempre bom lembrar que a educação não se reduz à escolarização. Ela é um amplo processo, constituinte da nossa humanização, que se realiza em diversos espaços sociais: na família, na comunidade, no trabalho, nas ações coletivas, nos grupos culturais, nos movimentos sociais, na escola, entre outros. Como nos diz Carlos Rodrigues Brandão (1981):

A educação é, como outras, uma fração do modo de vida dos grupos sociais que a criam e recriam, entre tantas outras invenções de sua cultura, em sua sociedade. Formas de educação que produzem e praticam, para que elas reproduzam, entre todos os que ensinam-eaprendem, 0 saber que atravessa as palavras da tribo, os códigos sociais de conduta, as regras do trabalho, os segredos da arte ou da religião, do artesanato ou da tecnologia que qualquer povo precisa para reinventar, todos os dias, a vida do grupo e a de cada um de seus sujeitos, através de trocas sem fim com a natureza e entre os homens, trocas que existem dentro do mundo social onde a própria educação habita, e desde onde ajuda a explicar às vezes a ocultar, a necessidade da existência de sua ordem. (p. 10-11)

Consideramos, assim, que existem diferentes e diversas formas e modelos de educação, e que a escola não é o lugar privilegiado onde ela acontece e nem o professor é o único responsável pela sua prática. Essa reflexão é importante para se pensar os processos edu-cativos, quer sejam escolares ou não-escolares. Muitas vezes, as práticas educativas que acontecem paralelamente à educação escolar, desenvolvidas por grupos culturais, ONG's, movimentos sociais e grupos juvenis precisam ser considerados pelos educadores escolares como legítimas e formadoras. Elas também precisam ser estudadas nos processos de formação de professores.

Apesar de levar em conta essa dimensão mais ampla e mais geral do processo educativo, neste artigo pretendo privilegiar a educação que acontece no interior da instituição escolar, tentando, porém, compreendê-la inserida no processo cultural e articulada com outros espaços educativos não-escolares. A escola é vista, aqui, como uma instituição em que aprendemos e compartilhamos não só conteúdos e saberes escolares mas, também, valores, crenças e hábitos, assim como preconceitos raciais, de gênero, de classe e de idade. É essa visão do processo educativo escolar e sua relação com a cultura e a educação - vista de uma maneira mais ampla - que nos permite aproximar e tentar compreender melhor os 
caminhos complexos que envolvem a construção da identidade negra e sua articulação com os processos formativos dos professores e das professoras. É também essa visão que nos possibilita compreender a presença da dimensão educativa em diferentes espaços sociais e não somente no interior da escola.

Mas como a identidade negra se articula com a cultura e com a educação? Um caminho interessante para refletir sobre essa articulação seria não pensar a identidade negra como a única possível de ser construída pelos sujeitos que pertencem a esse grupo étnico/racial. Entre as múltiplas identidades sociais que os negros e as negras constroem, a identidade negra é uma delas.

A reflexão sobre a construção da identidade negra não pode prescindir da discussão sobre a identidade como processo mais amplo, mais complexo. Esse processo possui dimensões pessoais e sociais que não podem ser separadas, pois estão interligadas e se constroem na vida social.

Como sujeitos sociais, é no âmbito da cultura e da história que definimos as identidades sociais (todas elas, e não apenas a identidade racial, mas também as identidades de gênero, sexuais, de nacionalidade, de classe, etc.). Essas múltiplas e distintas identidades constituem os sujeitos, na medida em que estes são interpelados a partir de diferentes situações, instituições ou agrupamentos sociais. Reconhecer-se numa delas supõe, portanto, responder afirmativamente a uma interpelação e estabelecer um sentido de pertencimento a um grupo social de referência. Nesse processo, nada é simples ou estável, pois essas múltiplas identidades podem cobrar, ao mesmo tempo, lealdades distintas, divergentes, ou até contraditórias. Somos, então, sujeitos de muitas identidades e essas múltiplas identidades sociais podem ser, também, provisoriamente atraentes, parecendo-nos, depois, descartáveis; elas podem ser, então, rejeitadas e abandonadas. Somos, desse modo, sujeitos de identidades transitórias e contingentes. Por isso as identidades sociais têm caráter fragmentado, instável, histórico e plural (Louro, 1999).

Assim, como em outros processos identitários, a identidade negra se constrói gradativamente, num processo que envolve inúmeras variáveis, causas e efeitos, desde as primeiras relações estabelecidas no grupo social mais íntimo, em que os contatos pessoais se estabelecem permeados de sanções e afetividade e no qual se elaboram os primeiros ensaios de uma futura visão de mundo. Geralmente tal processo se inicia na família e vai criando ramificações e desdobramentos a partir das outras relações que 0 sujeito estabelece.

A identidade negra é entendida, aqui, como uma construção social, histórica, cultural e plural. Implica a construção do olhar de um grupo étnico/racial ou de sujeitos que pertencem a um mesmo grupo étnico/racial sobre si mesmos, a partir da relação com o outro.

Construir uma identidade negra positiva em uma sociedade que, historicamente, ensina ao negro, desde muito cedo, que para ser aceito é preciso negar-se a si mesmo, é um desafio enfrentado pelos negros brasileiros. Será que, na escola, estamos atentos a essa questão? Será que incorporamos essa realidade de maneira séria e responsável quando discutimos, nos processos de formação de professores, sobre a importância da diversidade cultural?

Nesse sentido, quando pensamos a articulação entre educação, cultura e identidade negra, falamos de processos densos, movediços e plurais, construídos pelos sujeitos sociais no decorrer da história, nas relações sociais e culturais. Processos que estão imersos na articulação entre 0 individual e 0 social, entre o passado e o presente, entre a memória e a história.

Nessa perspectiva, quando pensamos a escola como um espaço específico de formação, inserida num processo educativo bem mais amplo, encontramos mais do que currículos, disciplinas escolares, regimentos, normas, projetos, provas, testes e conteúdos. A escola pode ser considerada, então, como um dos espaços que interferem na construção da identidade 
negra. 0 olhar lançado sobre o negro e sua cultura, na escola, tanto pode valorizar identidades e diferenças quanto pode estigmatizá-las, discriminá-las, segregá-las e até mesmo negá-las.

É importante lembrar que a identidade construída pelo negro se dá não só por oposição ao branco mas, também, pela negociação, pelo conflito e pelo diálogo com este. As diferenças implicam processos de aproximação e distanciamento. Nesse jogo complexo, vamos aprendendo, aos poucos, que as diferenças são imprescindíveis na construção da nossa identidade.

Sendo entendida como um processo contínuo, construído pelos negros nos vários espaços - institucionais ou não - nos quais circulam, podemos concluir que a identidade negra também é construída durante a trajetória escolar desses sujeitos. Nesse percurso, os negros deparam-se, na escola, com diferentes olhares sobre o seu pertencimento racial, sobre a sua cultura, sua história, seu corpo e sua estética. Muitas vezes esses olhares chocam-se com a sua própria visão e experiência da negritude. Estamos no complexo campo das identidades e das alteridades, das semelhanças e diferenças e, sobretudo, diante das diversas maneiras como estas são tratadas pela sociedade.

\section{Representações e impressões sobre o corpo negro: uma questão colocada para a formação de professores}

Ultimamente, alguns pesquisadores que trabalham com formação de professores, currículo e história da educação, (Veiga, 2000; Canen; Moreira, 2001; Apple, 2001, entre outros) têm se aproximado mais dos estudos sobre negro e educação, desenvolvendo pesquisas que articulam educação dos negros e memória; currículo e multiculturalismo, formação de professores e diversidade cultural. Tal aproximação faz parte de um movimento interessante que vem ocorrendo na produção teórica educacional sobre relações raciais no Brasil. ${ }^{2}$ Aqueles que já estão realizando esse movimento, aos poucos, vão descobrindo como esse campo ainda é incipiente e que, apesar do aumento da produção teórica sobre negro e educação, nos últimos anos no Brasil, ainda há muito trabalho a fazer. Um destes temas pouco explorados no âmbito da formação de professores evidenciou-se durante a realização de uma pesquisa etnográfica em salões étnicos de Belo Horizonte, que desenvolvi para a conclusão do doutorado em Antropologia Social na Universidade de São Paulo: a relação entre negro, corpo e estética.

Essa pesquisa teve como enfoque principal a relação entre negro, cultura e estética corporal. Durante as entrevistas, vários depoentes, homens e mulheres, jovens e adultos na faixa de 21 a 60 anos, ao retomarem momentos significativos da sua história de vida, relacionados com a dimensão estética, destacaram a sua passagem pela escola.

Assim, embora não tivesse como foco principal a formação de professores, ao refletirmos sobre as experiências e os depoimentos das cabeleireiras, dos cabeleireiros e clientes dos salões étnicos sobre suas vivências escolares, no que se refere ao corpo negro e ao cabelo crespo, fatalmente somos questionados sobre a formação dos docentes. E ao considerarmos a relação entre as representações sobre o corpo negro e os processos de formação de professores, alguns questionamentos vêm à tona: como os educadores negros e brancos pensam o próprio corpo? Como pensam e vêem o corpo negro? Durante os processos de formação docente, os educadores têm contato com reflexões que discutem as representações construídas em nossa sociedade sobre o negro, sua estética, sua ascendência africana e as formas como estas se misturam com situações de racismo, discriminação e preconceito racial? Como os professores lidam com as diferenças

2. É importante citar o Concurso Negro e Educação, iniciativa promovida pela Associação Nacional de Pós-Graduação e Pesquisa em EducaçãoANPEd em parceria com a Ação Educativa, Assessoria, Pesquisa e Informação, com apoio da Fundação Ford. Além das pesquisas, o concurso tem realizado seminários, debates e publicações sobre a temática. No ano de 2003 já foi lançado o III Concurso, que está em andamento. 
étnico-raciais inscritas no seu próprio corpo e no corpo de suas alunas e de seus alunos?

Para as pessoas entrevistadas durante a realização da pesquisa (Gomes, 2002), a experiência com o corpo negro e o cabelo crespo não se reduz ao espaço da família, das amizades, da militância ou dos relacionamentos amorosos. A escola aparece em vários depoimentos como um importante espaço no qual também se desenvolve o tenso processo de construção da identidade negra. Lamentavelmente, na maioria das vezes, a instituição escolar aparece nas lembranças dos depoentes reforçando estereótipos e representações negativas sobre o negro e o seu padrão estético.

A pesquisa revelou que, no processo de construção da identidade, o corpo pode ser considerado como um suporte da identidade negra e o cabelo crespo como um forte ícone identitário. Será que, ao pensarmos a relação entre escola, cultura, relações raciais e de gênero nos processos de formação de professores, levamos em conta a radicalidade dessas questões?

0 papel desempenhado pela dupla cabelo e cor da pele na construção da identidade negra foi o ponto de maior destaque durante a realização da pesquisa. A importância desses, sobretudo do cabelo, na maneira como o negro se vê e é visto pelo outro, até mesmo para aquele que consegue algum tipo de ascensão social, está presente nos diversos espaços e relações nos quais os negros se socializam e se educam: a família, as amizades, as relações afetivo-sexuais, o trabalho e a escola. Para esse sujeito, o cabelo carrega uma forte marca identitária e, em algumas situações, é visto como marca de inferioridade (Gomes, 2002).

Porém, existem outros espaços em que 0 cabelo é visto numa perspectiva de revalorização. São eles: os contextos familiares em que se preserva a memória ancestral africana, alguns espaços da militância política, os salões étnicos, entre outros. Essa revalorização extrapola o indivíduo e atinge o grupo étnico/racial a que pertence. Ao atingi-lo, acaba remetendo, às vezes de forma consciente e outras não, a uma ancestra- lidade africana recriada no Brasil. Lamentavelmente, a escola não aparece entre esses espaços de revalorização da estética, do corpo negro e do cabelo crespo. Por que será?

Compreender a complexidade na qual a construção da identidade negra está inserida, sobretudo quando levamos em consideração a corporeidade e a estética, é uma das tarefas e desafios colocados para os educadores. Deveria, também, ser uma das preocupações dos processos de formação de professores quando estes discutem a diversidade étnico-cultural. Os professores trabalham cotidianamente com o seu próprio corpo. 0 ato de educar envolve uma exposição física e mental diária. Porém, ao mesmo tempo em que se expõem, os educadores também lidam com o corpo de seus alunos e de seus colegas. Esses corpos são tocados, sentidos. A relação pedagógica não se desenvolve só por meio da lógica da razão científica mas, também, pelo toque, pela visão, pelos odores, pelos sabores, pela escuta. Estar dentro de uma sala de aula significa colocar a postos, na interação com o outro, todos os nossos sentidos.

Somos sujeitos corpóreos e usamos 0 nosso corpo como linguagem, como forma de comunicação. 0 que será que o aluno negro nos comunica por meio de seu corpo? Com a sua postura? Pela maneira como cuida do seu corpo? Como ele se apresenta esteticamente? Por outro lado, quais são as representações que nós, docentes, construímos desde a infância sobre o negro, seu corpo e sua estética? Será que essas representações, quando negativas, tornam-se mais fortes no exercício do trabalho docente, a ponto de nos tornar cegos e surdos para entender o que os nossos alunos tentam nos comunicar? Quantas vezes não ouvimos frases como "o negro fede"; "o cabelo rastafari é sujo e não se pode lavá-10"; "0 negro que alisa o cabelo tem desejo de embranquecer"; "aquele é um negro escovadinho"; "por que você não penteia esse cabelo pixaim"; "esses meninos de hoje usam roupas estranhas, parecem pivetes"? Quantas vezes essas frases não são repetidas pelos próprios 
docentes, dentro de sala de aula, nas conversas informais e nos conselhos de classe? Quantas vezes essas frases não são emitidas nos corredores das faculdades de educação e nas universidades?

\section{Como a escola lida com o corpo negro e o cabelo crespo?}

0 corpo localiza-se em um terreno social conflitivo, uma vez que é tocado pela esfera da subjetividade. Ao longo da história, o corpo se tornou um emblema étnico e sua manipulação tornou-se uma característica cultural marcante para diferentes povos. Ele é um símbolo explorado nas relações de poder e de dominação para classificar e hierarquizar grupos diferentes. 0 corpo é uma linguagem e a cultura escolheu algumas de suas partes como principais veículos de comunicação. 0 cabelo é uma delas.

0 cabelo é um dos elementos mais visíveis e destacados do corpo. Em todo e qualquer grupo étnico ele é tratado e manipulado, todavia a sua simbologia difere de cultura para cultura. Esse caráter universal e particular do cabelo atesta a sua importância como símbolo identitário.

0 entendimento da simbologia do corpo negro e dos sentidos da manipulação de suas diferentes partes, entre elas, o cabelo, pode ser um dos caminhos para a compreensão da identidade negra em nossa sociedade. Pode ser, também, um importante aspecto do trabalho com a questão racial na escola que passa despercebido pelos educadores e educadoras. Em torno da manipulação do corpo e do cabelo do negro existe uma vasta história. Uma história ancestral e uma memória. Há, também, significações e tensões construídas no contexto das relações raciais e do racismo brasileiro. A discussão sobre a riqueza do trato do corpo negro e sobre os processos de opressão que o mesmo tem recebido ao longo da história pode vir a ser uma rica atividade pedagógica a ser desenvolvida com os alunos e as alunas em sala de aula, possibilitando debates e atividades sobre a história e a cultura afro-brasileira. Nesse processo, um estudo sobre o negro, o cabelo crespo e as práticas corporais pode ser um bom caminho.

Destacar a existência de uma positividade nas práticas do negro diante do cabelo, hoje, quer seja trançando, implantando ou alisando0 , pode ser um interessante exercício intelectual que nos afasta das análises que primam pelo olhar da introjeção do branqueamento. Poderemos resgatar e encontrar muitas semelhanças entre algumas técnicas de manipulação do cabelo realizadas pelos negros contemporâneos e aquelas que eram desenvolvidas pelos nossos ancestrais africanos, a despeito do tempo e das mudanças tecnológicas. Esse processo pode ser visto como a presença de aspectos inconscientes, como formas simbólicas de pensar o corpo oriundas das diversas etnias africanas das quais somos herdeiros e que não se perderam totalmente na experiência da diáspora. Em todos esses momentos, a busca da beleza por meio da manipulação do cabelo destaca-se como uma virtualidade histórica e atuante. Esta é uma questão que merece ser trabalhada nos processos de formação de professores quando se pretende estudar a questão racial.

Mas como a escola lida com o corpo negro, o cabelo crespo e a cultura negra? Como as crianças, adolescentes, jovens e adultos negros são vistos e se vêem na escola? Para respondermos a essas questões teremos que nos aproximar dos homens e mulheres negras que já passaram pela escola e também daqueles que ainda estão realizando a sua trajetória escolar e escutar, atentamente, o que eles têm a nos dizer, como a dona de casa $M_{\text {., }}$ de 29 anos:

M.: Ah! Antigamente tinha muita gozação. Às vezes chamavam de cabelo frito... ah... muita gozação. Cabelinho ruim, muita coisa assim, agora não.

N.: Você acha que isso mudou?

M.: Hum... um pouco. Mudou um pouco. Hoje em dia, os negros não querem ficar pra trás não. 
N.: E isso que você disse: cabelinho frito, cabelinho ruim. Em que lugares Ihe falavam isso?

M.: Em escolas... escola, danceteria que a gente ia...

$\mathrm{N} .:$ Isso era muito falado?

M.: Tinha, e como tinha! Até os próprios negros falavam. Hoje em dia já é diferente. (...) É que hoje tem muitas opções e antigamente não tinha. Eu e a minha cabeleireira mesmo, nós falamos: "Nossa menina! Na nossa época da escola! A gente ia com o cabelinho horrível pra escola". Agora não, você pode escolher tudo para o cabelo. 0 cabelo (...) você quer azul, do jeito que você quer, você põe. Agora tem opção, agora é diferente. Agora o negro fica do jeito que ele quer. Você vê que tem até negro loiro aí, antigamente não tinha. Era só aquilo e aquilo mesmo. Os negros que andavam com cabelo arrumado, eram os que tinham dinheiro, porque antigamente era caríssimo ir ao salão. Hoje em dia, não.

É interessante constatar que o depoimento expressa uma mudança, nos dias de hoje, em relação à representação construída sobre o negro e seu cabelo, às possibilidades econômicas e ao acesso aos espaços de beleza que cuidam do corpo do negro e do cabelo crespo. Essa mudança também possibilita ao negro apresentar-se esteticamente de uma maneira considerada mais "aceitável" socialmente, o que pode ter contribuído para a diminuição dos apelidos e tratamentos preconceituosos nos espaços públicos, entre eles, a escola. Será que essa mudança se deve somente à invenção das novas técnicas de pentear e alisar o cabelo apontadas pela depoente? Ou seja, não mais o "cabelo frito" pelo pente quente, mas o cabelo "relaxado" via produtos químicos de maior qualidade ou "alongado" via processos mais variados de implantes, ou mesmo o "careca" cortado com máquina um? Ou será que essa mudança implica alguma alteração na forma como o pró- prio negro contemporâneo lida com a diferença racial inscrita no seu corpo e no seu tipo de cabelo? Ou ainda: será que as manifestações de preconceito estão diminuindo dentro do atual espaço escolar?

$\mathrm{Não}$ podemos deixar de pontuar que a sociedade e a escola brasileira da atualidade têm construído representações sociais mais positivas sobre o negro e sua estética. É o que nos fala a depoente acima. Essa transformação, sem dúvida, não se dá por honra e glória da educação escolar. Se pesquisarmos mais a fundo, encontraremos a ação da comunidade negra organizada em movimentos sociais, dos grupos culturais negros, das comunidades-terreiro como partes importantes no processo de denúncia contra o racismo e de afirmação da identidade negra. Encontraremos também famílias negras que, atentas aos dilemas de seus filhos e filhas, enfatizam de forma positiva e de diversas maneiras a herança cultural negra. Esses grupos e essas famílias sempre pressionaram a escola e sempre cobraram desta instituição uma responsabilidade social e pedagógica diante da questão racial. Porém, essa pressão não se limita à escola. Ela atinge a sociedade como um todo e, aos poucos, tem tornado possível uma lenta inserção social do negro em alguns setores do mercado de trabalho, a sua presença (mesmo tímida) nos meios de comunicação e nos veículos publicitários e a sua entrada em maior número na educação básica. Somando-se aos outros grupos sociais que lutam pela democratização da sociedade, a comunidade negra tem conseguido mudar, aos poucos, a situação do negro no Brasil. Mas ainda há muito que avançar.

Nesse processo lento e tenso, alguns negros, desde muito cedo, aprendem a posicionar-se de maneira afirmativa e a reagir à discriminação racial. Muitas crianças negras percebem, desde muito cedo, que ser chamada de "negrinha" nem sempre significa um tratamento carinhoso, pelo contrário, é uma expressão do racismo. Nesse contexto, cada um luta com as armas que tem: 
B.: Eu era muito bagunceira na escola, nunca deixei que ninguém me chamasse de negrinha na escola, porque eu batia neles mesmo! Então quando eu chegava em casa meu pai me batia e, no outro dia, eu batia no menino de novo, e fui fazendo aquela coisa... Na escola os meninos chegavam e me respeitavam... eu era a única negrinha da sala, então eles diziam: "Ah, eu não vou mexer com ela não, porque ela bate na gente". Eu pedia merenda, porque eu não tinha condições de comprar merenda e os meninos me davam merenda. Quando não me davam eu batia neles e eles me davam a merenda. (B. 38 anos, cabeleireira étnica)

Mas nem todos sabem se defender dos xingamentos preconceituosos. As experiências de preconceito racial vividas na escola, que envolvem o corpo, o cabelo e a estética, ficam guardadas na memória do sujeito. Mesmo depois de adultos, quando adquirem maturidade e consciência racial que Ihes permitem superar a introjeção do preconceito, as marcas do racismo continuam povoando a sua memória. A ausência da discussão sobre essas questões, tanto na formação dos professores quanto nas práticas desenvolvidas pelos docentes na escola básica, continua reforçando esses sentimentos e as representações negativas sobre o negro. Nem sempre os professores e as professoras percebem que, por detrás da timidez e da recusa de participação de trabalhos em grupos, encontra-se um complexo de inferioridade construído, também, na relação do negro com a sua estética durante a sua trajetória social e escolar.

N.: Teve uma época, isso foi na quarta série, eu estudei... quando eu fiz 12 anos, eu estudei no Bernardo Monteiro. Eu era a única negra lá da sala. No Bernardo Monteiro, na parte da manhã, na época, era classe média alta. Mas, na realidade, eu não me lembro se eu era a única negra da sala, eu sei que meu cabelo era batidinho e os meninos me chamavam de Paulo Isidoro. Ah! Eu odiava! Ele era um jogador de futebol, nossa, era tanta coisa! Tinha uma turminha de rapazes, então, a gente estava começando a se interessar por rapazes. Mas assim, eu jamais ia me interessar por alguém, porque eu jamais ia imaginar que alguém ia se interessar por mim. E tinha as meninas da sala que jogavam piadinhas, entendeu? Tanto que eu tive que sair do colégio porque meu rendimento era péssimo. Eu não conversava com ninguém... eu odiava responder presente durante a chamada, ir à lousa... nem pensar! Me chamavam de Paulo Isidoro, que eu era isso, era aquilo, entendeu? As meninas tudo burguesinhas, de cabelão, a maioria, loira e tal. Eu não tinha amiga nenhuma, porque jamais elas chegavam perto de mim. Eu tinha uma só, que era assim, bem negona, fortona. Ela era a minha colega, eu tinha só ela, porque nós duas ficávamos assim: as excluídas da sala. (N. cabeleireira étnica, 26 anos)

Mas as experiências negativas vividas na escola por causa do cabelo crespo, reveladas pela depoente, não param por aí. Quando experimentava diferentes maneiras e técnicas de arrumar o cabelo, mesmo que fossem aquelas que se aproximavam do padrão de cabelo liso, a então adolescente negra era vista com estranhamento e com hostilidade pelos colegas. Até mesmo hoje, depois de adultas, as mulheres negras continuam enfrentando um verdadeiro "patrulhamento ideológico" em relação à sua estética. Alguns as desejam com o cabelo "crespo natural", considerado por um grupo como autêntica expressão da negritude; outros querem-nas de tranças, por julgarem que esse penteado aproxima a mulher (e o homem negro) de suas raízes africanas; outros, com o cabelo alisado, por considerarem que tal penteado aproxima as mulheres negras do padrão estético branco, visto socialmente como o mais belo. Enfim, esse tipo de cerceamento da liberdade 
da expressão estética e corporal do negro, sobretudo da mulher negra, demonstra que continuamos mergulhados nas malhas do racismo e do preconceito racial. Na realidade, o que pode parecer uma simples opinião ou um mero julgamento estético, revela a existência de uma tensão racial, fruto do racismo ambíguo e do ideal do branqueamento desenvolvidos no Brasil. Essas questões deveriam ser consideradas com mais seriedade pelos educadores e pelas educadoras. Vejamos o que N. nos diz, continuando seu depoimento:

N.: Quando eu era mais nova eu ia pra escola e eu tinha o cabelo de trancinha. Eu me lembro de uma vez, estava na quarta série... Ai, meu Deus, eu não esqueço!...., tem coisa que marca, a gente não esquece. Eu estava na aula, então, eu usava trancinha. Um dia minha mãe resolveu tirar minha trancinha e alisar meu cabelo. Eu alisei meu cabelo, eu lembro como se fosse hoje. Eu lembro, minha mãe alisou... foi no salão, alisou, ficou assim, balançando ao vento. Ficou lindo meu cabelo, maraviIhoso! Só que eu fiquei com vergonha de sair do salão com o cabelo, porque estava bonito, eu fiquei com vergonha, porque estava bonito e ia chamar a atenção. Então eu fui pra aula. Eu sempre sentei mais perto da primeira carteira, só que eu sentava perto da janela. Eu quase entrei dentro do armário pra ficar escondida, por causa do cabelo. E tinha um menino branquinho, o Leonardo, lindo, do olho azul, branquinho, que sentava na primeira carteira. Eu parti o cabelo de lado, coloquei um passadorzinho com umas pedrinhas de strass. 0 pessoal olhou, lógico que iam reparar, eu tinha o cabelo de trancinha e eles falaram assim: "Nossa, você está diferente hoje, arrumou o cabelo!". E um menino falou: "Ficou mais feia ainda". Aquilo foi a morte, depois que ele falou aquilo, nem pra aula eu queria ir mais. Não queria ir pra aula.
É importante destacar no testemunho acima não somente as relações de ciúmes e disputas desenvolvidas dentro dos grupos de adolescentes que competem entre si, no interior da escola, em termos de beleza, esperteza, "inteligência", paqueras, mas também uma outra questão igualmente importante: os sentimentos que a depoente desenvolvia em relação à sua própria aparência, dando um destaque maior ao cabelo e à maneira como ele era visto pelo outro, pelos colegas. Somente no dia em que ela chegou à escola com o cabelo alisado é que lhe disseram: "Nossa, você está diferente hoje, arrumou o cabelo!". É interessante pensar que somente quando ela se apresentou com um penteado próximo do padrão "branco", ou seja, do cabelo liso, é que ela pôde receber o reconhecimento dos outros de que arrumara e penteara o cabelo. Ora, se a própria depoente nos diz que quando ia à escola "eu tinha o cabelo de trancinha (...) Eu estava na aula, então, eu usava trancinha (...)", podemos concluir que usar o cabelo com trancinha não era considerado pelos colegas como "arrumado", ou seja, penteado. No entanto, o uso das tranças pelos negros, além de carregar toda uma simbologia originada de uma matriz africana ressignificada no Brasil, é, também, um dos primeiros penteados usados pela criança negra e privilegiados pela família. Fazer as tranças, na infância, constitui um verdadeiro ritual para essa família. Elaborar tranças variadas no cabelo das filhas é uma tarefa aprendida e desenvolvida pelas mulheres negras.

Embora, à primeira vista, os comentários dos colegas pudessem parecer ingênuos, $N$. demonstra que entendeu a mensagem racial contida no seu interior. Compreendeu também 0 peso negativo que ela carregava e, pelo visto, durante anos ficou marcada e presa a esse lugar que lhe impuseram: o lugar da inferioridade. Será que tal situação deixou de existir? Será que comentários como esses não acontecem mais em nossas salas de aula? E como eles repercutem nos sujeitos que os enunciam e naqueles que os recebem? 


\section{Ressignific ação da identidade negra por meio do corpo e do c a belo}

Mas, como já foi dito anteriormente, 0 processo de construção da identidade negra é muito mais complexo, instável e plural. Apesar das marcas negativas deixadas pelas experiências de discriminação, o negro se reconstrói positivamente. É claro que esse processo não se dá no isolamento e varia de pessoa para pessoa. Existem diferentes espaços e agentes que interferem no processo de rejeição/aceitação/ressignificação do ser negro. Pode ser a família, a participação em espaços políticos, a atuação de um professor ou professora, a construção de uma amizade ou de um relacionamento amoroso ou, no caso da depoente anteriormente citada, o envolvimento com a questão racial via estética: profissionalizando-se como cabeleireira étnica.

Esse lugar construído positivamente, a partir da sua própria diferença, garantiu à cabeleireira étnica entrevistada legitimidade diante da professora e dos colegas da escola. A construção desse lugar, sem o esquecimento das experiências difíceis vividas na infância e narradas anteriormente, possibilitou a sua formação como mãe e mulher negra atenta e sensível para com a construção da identidade racial de outros negros e negras.

No depoimento abaixo, vemos como a postura de uma professora mais atenta ao lugar ocupado pela aluna negra no interior da sala, somada a uma desenvoltura maior de N. em relação à questão racial e sua identidade negra, abriram caminho para que a aluna viesse a falar sobre "cabelo" em um dos trabalhos solicitados. A menina negra, que antes tinha medo de se posicionar diante do outro e até mesmo de responder à chamada, torna-se, agora, o centro das atenções ao falar sobre a questão racial de forma positiva, a partir do próprio ofício:

N.: Foi a professora de inglês, sim. 0 trabaIho era sobre... sobre o tema: poderíamos falar sobre o clima dos Estados Unidos, so- bre a população, etc. Ela falou que a gente podia escolher a área, só que tinha que ser sobre os norte-americanos (...) Eu falei: "Então tá, eu vou fazer sobre o cabelo!". E ela: "Ah, só podia ser sobre o cabelo!". Eu fiz, ela adorou o trabalho, vou te mostrar, eu acho que está aqui. Ela adorou o trabaIho, queria ficar com o trabalho pra ela e eu falei: "Não, vou tirar um xerox colorido e vou te passar...". Então fiz assim: sobre o cabelo étnico, entendeu? Desde quando começou até hoje, lá, nos Estados Unidos. E ela achou superlegal! (...) Eu entrei esse ano novamente no colégio (...). 0 pessoal sabe que eu tenho salão e então me perguntam tudo sobre o cabelo... Às vezes está passando uma matéria e eles falam: "N. o meu cabelo..."; e a outra: "N., o meu cabelo...". Sabe? Tudo é sobre o cabelo! 0 pessoal de outra sala, no recreio, me chama: "N., eu queria um banho de creme no meu cabelo...". Porque lá, nesse colégio, são pessoas assim, a maioria é da área da Ventosa, Morro das Pedras, então o pessoal não tem condições, acha caríssimo! 0 pessoal ganha de um salário mínimo pra baixo! Teve uma menina da minha sala que falou: "Eu queria tanto ir no seu salão mas pelas suas fotos eu acho que eu não vou ter condições de pagar...". Olha só! Só pelas fotos do salão que eu mostrei na sala. E eu falei para ela: "Não, não tem nada disso, engano seu. Quanto você paga para fazer escova?". "Doze reais", ela disse. Eu falei: "Pois é, no meu salão você só pagaria oito". "Ah, é mesmo?" Eu falei: "É!". Ela ficou toda satisfeita, foi ao salão e fez a escova. (N. 26 anos, cabeleireira étnica)

Certamente, se essa professora fosse adepta de uma prática pedagógica conservadora ou "neutra" diante da questão racial, esse espaço não teria sido criado e o grupo de alunos negros e brancos daquela sala de aula não teria vivido uma experiência escolar tão interessante. 
Atentos à importância do trabalho com a questão racial e com a responsabilidade social da escola na desconstrução de estereótipos raciais, alguns estabelecimentos de ensino, sobretudo do setor público, já desenvolvem trabalhos e projetos voltados para a valorização da cultura negra. As escolas que percebem a importância de um trabalho coordenado com a comunidade, os movimentos sociais e profissionais negros que lidam no seu cotidiano com a questão racial, abrem as suas portas para um trabalho conjunto. É nesse momento que a articulação entre os espaços escolares e nãoescolares pode acontecer. No caso da pesquisa em questão, é também nesse momento que os salões de beleza étnicos e a escola desenvolveram, juntos, um trabalho positivo em relação à identidade negra. Certamente, esses projetos e iniciativas influenciam positivamente a construção da auto-estima e da identidade negra de crianças, adolescentes, jovens e também dos professores. É o que nos conta outra entrevistada:

D.: Então eu vou nas escolas, em várias escolas, fazendo trabalhos, penteando o cabelo dos garotos e faço desfiles. Às vezes, na escola, essas meninas que participam, que a gente produz dentro da escola, nós trazemos algumas para participar com a gente, em alguns desfiles que promovemos como, por exemplo, a Feira Mineira da Beleza. Teve a Primeira Feira Étnica de Belo Horizonte e eu trouxe meninas que participaram com a gente nesses desfiles nas escolas. Também teve aqui a Feira da Lagoinha e a gente trouxe as garotas e os garotos para participarem também. $E$ as meninas ficam muito contentes, muito felizes. Porque são meninas, assim, às vezes meninas carentes que nunca participaram de um desfile e a gente faz um trabalho com elas, aqui, no salão. A gente passa pra elas o que a gente pode passar... dentro do que a gente pode passar pra elas e elas vão pra passarela. (D. 46 anos, cabeleireira étnica)
Por isso, engana-se quem pensar que os jovens e adolescentes negros encontram-se sozinhos nesse denso e tenso processo de ressignificação da identidade negra, por meio do corpo e do cabelo, quando a escola não se abre para esse trabalho. Os espaços educativos não-escolares desempenham um papel importante nesse processo. Muitas vezes, esses locais não são percebidos como afirmativos e significativos por aqueles que a eles não têm acesso. No caso da pesquisa aqui relatada, os salões de beleza étnicos apresentam-se como alguns desses espaços educativos não- escolares.

Os salões étnicos apresentam, no seu interior e na sua constituição, todas as tensões e ambigüidades que envolvem a construção da identidade negra no Brasil. Porém, não é só isso. Eles se destacam como espaços de resistência. Revelam-se como algo muito além de microempresas ou lugares de "embranquecimento", como julgam algumas pessoas. Eles são espaços da comunidade negra. As pessoas que por ali circulam e as que ali trabalham enfrentam, cotidianamente, o desafio de "lidar" com as questões concernentes à construção da identidade negra. Nesses espaços, a identidade negra, enquanto processo, é problematizada, discutida, afirmada, negada, encoberta, rejeitada, aceita, ressignificada e recriada. Tudo isso acontece ao mesmo tempo e, nesse sentido, os salões étnicos nos colocam no cerne das tensões e também das possibilidades de recriação vividas por homens, mulheres, crianças, adolescentes, jovens e adultos negros.

E.: E isso foi passado, assim, não só na família mas também na escola, com os amigos. Às vezes eu pensava: "Aquela ali tem 0 cabelo assim e tal! Então eu não vou ficar com ela porque o meu filho vai sair de cabelo duro...". E às vezes casais negros dizem: "Vou optar por não ter filho, porque eu não quero que os meus filhos sofram 0 mesmo preconceito que eu já senti". Então essa maturidade de que eu falo, eu venho adquirindo com o passar do tempo. Vendo, 
estudando, vendo que não é por aí, que eu tenho a minha identidade e eu, sabendo trabalhar, ela é uma coisa muito forte e marcante! Por isso que eu disse: hoje eu sei o meu espaço dentro da sociedade. E aprendi isso dentro do salão $D$. Cabeleireiros, isso me ajudou muito também, porque eu vou lá não é só para cortar o cabelo. Não é só pra mudar o estilo! Mas para gente ter um bate-papo também falando a esse respeito, falando a respeito do negro, porque sempre que a gente chega lá ela tem um assunto diferente pra tratar, uma curiosidade... E dentro disso tudo eu passei a pesquisar a cultura africana, também, porque eu faço um trabalho de contador de histórias... (E. 30 anos, relações- públicas)

Como já foi salientado anteriormente, esse papel de problematização, reconstrução e discussão sobre a identidade negra também deveria ser feito pela escola. Porém, muitas vezes, enquanto uma instituição formadora, contraditoriamente, a escola apresenta-se menos eficaz e menos sensível diante desse processo.

\section{Conc lus ão}

0 estudo sobre as representações do corpo negro no cotidiano escolar poderá ser uma contribuição não só para o desvelamento do preconceito e da discriminação racial na escola como, também, poderá nos ajudar a construir estratégias pedagógicas alternativas que nos possibilitem compreender a importância do corpo na construção da identidade étnico-racial de alunos, professores negros, mestiços e brancos e como esses fatores interferem nas relações estabelecidas entre esses diferentes sujeitos no ambiente escolar. Na escola, não só aprendemos, mas também reproduzimos representações sobre o cabelo crespo e o corpo negro. Quais serão essas representações? Em que momentos aparecem e como elas aparecem? Como os sujeitos negros e brancos vi- vem esses processos dentro e fora da escola? Como tais representações se manifestam no currículo? Muitas vezes, esses processos delicados e tensos passam despercebidos pela escola, pelos profissionais da educação, e não constituem motivo de debates e estudos nos nossos cursos de formação de professores.

0 estudo sobre o corpo e o cabelo como ícones da identidade negra presentes nos processos educativos escolares e não-escolares poderá nos apontar outros caminhos além da denúncia da reprodução de preconceitos e estereótipos. Ver a manipulação do cabelo do negro e da negra como continuidade de elementos culturais africanos ressignificados no Brasil poderá nos pôr em contato com a história, memória e herança cultural africana presente na formação cultural afro-brasileira.

Penso que tais estudos poderão e deverão fazer parte dos processos de formação de professores. A sua incorporação nos currículos e nos processos pedagógicos de formação docente faz parte de lutas e reivindicações históricas do movimento negro brasileiro que há anos tem demandado o ensino da história da África e da cultura afro-brasileira nos currículos escolares.

Atualmente, essa demanda já foi transformada em lei, a Lei 10.639 , de 09 de janeiro de 2003, que altera a Lei 9394/96 (Lei de Diretrizes e Bases da Educação Nacional). Essa nova lei inclui no currículo oficial dos estabelecimentos de ensino fundamental e médio, públicos e particulares, a obrigatoriedade do ensino da "história e cultura afro-brasileira".

0 primeiro parágrafo do artigo 26 da nova lei explicita que o conteúdo programático a ser desenvolvido pelas escolas no cumprimento da mesma deverá incluir o estudo da história da África e dos africanos, a luta dos negros no Brasil, a cultura negra brasileira e o negro na formação nacional, resgatando sua contribuição nas áreas social, econômica e política pertinentes à história do Brasil.

Esse é mais um desafio proposto não só para os professores, mas também para os centros 
de formação de professores. 0 que sabemos sobre história e cultura afro-brasileira? 0 que sabemos sobre história da África? Como não reproduzir leituras e discussões estereotipadas sobre o negro e sua cultura? Que temas deveremos privilegiar dentro do vasto campo de estudo sobre a cultura afro-brasileira? São questionamentos novos que os docentes e os cursos de formação de professores começarão a fazer.

Entender a importância da simbologia do corpo negro, a manipulação do cabelo e dos penteados usados pelos negros de hoje como formas de recriação e ressignificação cultural daquelas construídas pelos negros da diáspora poderá ser um bom tema de estudo e debate dentro da discussão sobre história e cultura afro-brasileira. Mas, para isso, será preciso que os educadores alterem suas lógicas escolares e conteudistas, dialoguem com outras áreas, valorizem a produção cultural negra constituída em outros espaços sociais e políticos. Será preciso também ouvir e aprender as estratégias, práticas e acúmulos construídos pelo movimento negro e pelos movimentos culturais negros. 0 campo da formação de professores deverá se abrir para dialogar com outros espaços em que negros constroem suas identidades. Muitas vezes, serão espaços considerados pouco convencionais pelo campo da educação, como por exemplo, os salões étnicos.

0 atual contexto de implementação da Lei 10.639 é um momento propício para a introdução no campo da formação de professores, quer seja inicial ou em serviço, de estudos e leituras sobre a relação corpo, cultura e identidade negra. 0 desafio está colocado. Resta agora entendermos que mais do que um desafio, a discussão sobre raça negra e educação, nos seus múltiplos desdobramentos, é um dever dos educadores e educadoras e também daqueles responsáveis pela condução dos processos de formação docente.

\section{Referências bibliográfic as}

APPLE, M. E. A presença ausente da raça nas reformas educacionais. In: CANEN, A.; MOREIRA, A. F. B. (Orgs.) Ênfases e omissões no currículo. São Paulo: Papirus, 2001. p.147-161.

BRANDÃO, C. R. O que é educação. São Paulo: Brasiliense, 1981.

CANEN, A.; MOREIRA, A. F. B. Reflexões sobre o multiculturalismo na escola e na formação docente. In: e omissões no currículo. São Paulo: Papirus, 2001. p.15-44. (Orgs.) Enfases

CUCHE, D. A noção de cultura nas ciências sociais. Trad. de Viviane Ribeiro. Bauru: Edusc, 1999.

D'ADESKY, J. Racismos e anti-racismos no Brasil: pluralismo étnico e multiculturalismo. Rio de J aneiro: Pallas, 2001.

GOMES, N. L. Corpo e cabelo como ícones de construção da beleza e da identidade negra nos salões étnicos de Belo Horizonte. 2002. Tese (Doutorado). Faculdade de Filosofia, Letras e Ciências Humanas da Universidade de São Paulo.

LARAIA, R. B. Cultura: um conceito antropológico. Rio de J aneiro: J orge Zahar, 2001.

LOURO, G. L. (Org.). O corpo educado: pedagogias da sexualidade. Belo Horizonte: Autêntica, 1999.

MUNANGA, K. "Arte afro-brasileira" o que é, afinal? In: Associação 500 Anos Brasil ArTes Visuals. Mostra do redescobrimento. Arte afrobrasileira. São Paulo: Fundação Bienal de São Paulo, 2000. p. 98-111.

QUEIROZ, R. S. (Org.) 0 corpo do brasileiro; estudos de estética e beleza. São Paulo: Senac, 2000.

QUEIROZ, R. S.; OTTA, E. A beleza em foco: condicionantes culturais e psicológicos na definição da estética corporal. In: QUEIROZ, R. S. (Org.) 0 corpo do brasileiro; estudos de estética e beleza. São Paulo: Senac, 2000. p. 13-66. 
RODRIGUES, J. C. 0 tabu do corpo. Rio de J aneiro: Dois Pontos, 1986.

VEIGA, C. G. Escola de alma branca: o direito biológico à educação no movimento da Escola Nova. Educação em Revista, Belo Horizonte, set., p.123-150, 2000. Edição especial.

Recebido em 14.03.03

Aprovado em 13.05.03

Nilma Lino Gomes é doutora em Antropologia Social pela USP e professora-adjunta do Departamento de Administração Escolar da Faculdade de Educação da Universidade Federal de Minas Gerais. 